\section{Health And Drug Alerts}

\section{Paroxetine (Paxil) and}

\section{congenital malformations}

Reason for posting: Selective serotonin reuptake inhibitors (SSRIs) have not previously been demonstrated, as a group, to be teratogenic. ${ }^{1}$ However, the results of an unpublished study ${ }^{2}$ by GlaxoSmithKline (GSK) has led the US Food and Drug Administration and Health Canada to warn that one SSRI, paroxetine, may increase the risk of major congenital malformations. ${ }^{3}$

The drug: Antidepressants, including paroxetine, are used to treat major depression, anxiety, obsessive-compulsive disorder and premenstrual dysphoria, all common disorders during the childbearing years. ${ }^{4}$ GSK, the manufacturer of paroxetine and another antidepressant, bupropion, recently completed an unpublished retrospective study of data from 2 US managed-care insurance databases. Pregnancy outcomes among 358I expectant mothers aged I2-49 years who were taking antidepressants were studied.

Initially, the study sought to investigate whether women prescribed buproprion had infants with higher rates of cardiovascular malformations than women either taking other antidepressants or taking the drug in the third trimester only. Any cardiac or serious congenital malformation was recorded for users of bupropion in the first or third trimester and users of any other antidepressants. The analysis excluded women with concurrent first-trimester use of known teratogens, including lithium, valproic acid and carbamazepine.

Children exposed to bupropion in the first or third trimester did not have increased rates of malformations relative to those taking any antidepressant. The FDA, however, requested a secondary analysis of specific rates of malformations among infants of users of all other antidepressants. There were 18 used in total, including SSRIs, tricyclics, serotonin-norepinephrine-reuptake inhibitors and other new antidepressants.

Only users of paroxetine had an increased risk of malformations higher

\begin{tabular}{|c|c|c|c|c|}
\hline Drug & $\begin{array}{c}\text { Maternal } \\
\text { users }\end{array}$ & $\begin{array}{c}\text { Infant } \\
\text { mal- } \\
\text { formations }\end{array}$ & $\begin{array}{c}\text { Malformations } \\
\text { per } 1000 \\
\text { live births }\end{array}$ & $\begin{array}{c}\text { Adjusted } \\
\text { odds ratio } \\
(95 \% \mathrm{Cl}) \dagger\end{array}$ \\
\hline Amitriptyline & 146 & 1 & 6.8 & $0.27(0.04-1.96)$ \\
\hline Bupropion & 248 & 6 & 24.2 & $0.99(0.42-2.30)$ \\
\hline Citalopram & 188 & 7 & 37.2 & $1.39(0.62-3.11)$ \\
\hline Fluoxetine & 820 & 18 & 22.0 & $0.82(0.48-1.39)$ \\
\hline Nefazodone & 41 & 1 & 24.4 & $0.94(0.13-6.96)$ \\
\hline Paroxetine & 527 & 23 & 43.6 & $2.20(1.34-3.63)$ \\
\hline Sertraline & 507 & 7 & 13.8 & $0.48(0.22-1.05)$ \\
\hline Trazodone & 49 & 2 & 40.8 & $1.98(0.47-8.39)$ \\
\hline Venlafaxine & 129 & 2 & 15.5 & $0.59(0.14-2.42)$ \\
\hline $\begin{array}{l}>1 \text { type of } \\
\text { antidepressant }\end{array}$ & 406 & 14 & 34.5 & $1.42(0.79-2.55)$ \\
\hline
\end{tabular}

*Categories of specific antidepressants are mutually exclusive. Data were taken from a GlaxoSmithKline report ${ }^{2}$ (available at http://ctr.gsk.co.uk/summary/paroxetine/epip083.pdf [accessed 2005 Oct 26] and also at www.cmaj.ca/cgi/content/full/173/11/1320/DC1). Because no major congenital malformations were observed among the offspring of participants exposed to clomipramine, desipramine, doxepin, fluvoxamine, imipramine, mitrazapine, nortriptyline or protriptyline, data for these antidepressants are not shown. †Adjusted for age and sex of infant, calendar year of delivery and a maternal diagnosis of pre-eclampsia or eclampsia. The comparator group is the rate of malformations among infants of users of any other antidepressant in the first trimester. $\mathrm{Cl}=$ confidence interval.

than those of other antidepressants (Table I). Various organ systems (gastrointestinal, genitourinary and central nervous system) were affected in roughly equal proportions. The most common cardiovascular malformations seen were ventricular septal defects. ${ }^{2}$

The absolute rate of major congenital seen in the first trimester for paroxetine users was $4 \%$; of cardiovascular malformations, $2 \% .{ }^{3}$ This study did not include controls of women not taking an antidepressant; however, the prevalence of major congenital and cardiovascular malformations for all births in the United States, regardless of drug exposure, are $3 \%$ and $\mathrm{I} \%$, respectively. ${ }^{3}$

What to do: This study is limited by its retrospective design, its post hoc secondary analyses, the limited clinical details available in an insurance database, and its lack of controls. However, it is one of the first reasonably large epidemiologic studies to suggest possible teratogenicity of an SSRI. Why paroxetine may have this effect is not clear, and the results conflict with other epidemiologic studies performed to date. ${ }^{3}$ Although the relative risk increase of malformations is about twofold, the absolute risk increase over baseline malformation rates appears to be about I\% (i.e., about Ioo pregnant users would be needed before additional harm would come to one infant). Any woman of childbearing age being treated with paroxetine should be counselled on these absolute and relative risks. If pregnancy is a real possibility, consideration should be given to switching medications.

\section{Megan Williams}

Resident

Department of Family Medicine

University of Ottawa

Ottawa, Ont.

Eric Wooltorton

CMAJ

\section{REFERENCES}

I. Einarson TR, Einarson A. Newer antidepressants in pregnancy and rates of major malformations: a meta-analysis of prospective comparative studies. Pharmacoepidemiol Drug Saf 2005; Mar I [Epub ahead of print]. DOI:IO.IO02/pds.I084

2. GlaxoSmithKline study EPIPo83. GSK medicine: bupropion and paroxetine. Epidemiology study: preliminary report on bupropion in pregnancy and the occurrence of cardiovascular and major congenital malformation. Available: http://ctr.gsk.co .uk/summary/paroxetine/epipo83.pdf (accessed 2005 Oct 26); also archived at www.cmaj.ca/cgi /content/full/173/II/I320/DCI as an appendix.

3. Dillon AJ, for GlaxoSmithKline Inc., encorsed by Health Canada. New safety information regarding 
paroxetine. Findings suggest increased risk over other antidepressants, of congenital malformations, following first trimester exposure to paroxetine [Dear Health Care Professional letter]. Available: www.hc-sc.gc.ca/dhp-mps/medeff/advisories -avis/prof/paxil_3_hpc-cps_e.html (accessed 2005 Oct 26).

4. Hallberg P, Sjoblom V. The use of selective serotonin reuptake inhibitors during pregnancy and breast-feeding: a review and clinical aspects [review]. J Clin Psychopharmacol 2005;25:59-73.

Early release

All Health and Drug Alerts are posted online ahead of print and are available at www.cmaj.ca. This article was posted on Nov. 4, 2005.

\section{Canadian Adverse Reaction Newsletter Bulletin canadien des effets indésirables}

To receive the Newsletter and health product Advisories free by email, join Health Canada's MedEffect mailing list. Go to $w w w . h c-s c . g c . c a l d h p$-mps/medefflsubscribe-abonnement/index_e.html.

Inscrivez-vous à la liste MedEffet de Santé Canada pour recevoir gratuitement par courriel le Bulletin et les Avis au sujet des produits de santé. Rendez-vous à l'adresse www.hc-sc.gc.caldhp-mps/medefflsubscribe-abonnement/index_f.html.

Report adverse reactions toll free to Health Canada Signaler sans frais des effets indésirables à Santé Canada

Tel./Tél. : 866 234-2345• Fax/Téléc. : 866 678-6789

Canadä

\section{BOOKS RECEIVED}

Ahronheim JC, Huang Z-B, Yen V, Davitt $\mathrm{CM}$, Barile D. Case studies in geriatric medicine. New York: Cambridge University Press; 2005. 298 pp. \$55 ISBN 0-52I53175-6

Bhidayasiri R, Waters MF, Giza CC. Neurological differential diagnosis: a prioritized approach. Oxford (UK): Blackwell Publishing; 2005. 542 pp. \$49.50 ISBN I-405 I2039-8

Birmingham LC, Beaumont P. Medical management of eating disorders. Cambridge (UK): Cambridge University Press; 2004. 3I4 pp. \$73.95 ISBN 0-52I-54662-I

Blank RH, Merrick JC. End-of-life decision making: a cross-national study. Cambridge (MA): MIT Press; 2005. 266 pp. \$32 ISBN 0-262-02574-4

Brown MM, Brown GC, Sharma S. Evidence-based to value-based medicine. Chicago: AMA Press; 2005. 339 pp. $\$ 84.50$ ISBN I-57947-625-2

Cailliet $\mathrm{R}$. The illustrated guide to functional anatomy of the musculoskeletal system. Chicago: AMA Press; 2003. 310 pp. \$90.95 ISBN I-57947-408-X

Cerroni L, Gatter K, Kerl H. An illustrated guide to skin lymphoma. Oxford (UK): Blackwell Publishing; 2004. I86 pp. \$I8I.95 ISBN I-405I-I376-6

Chen S-A, Haissaguerre M, Zipes DP. Thoracic vein arrhythmias: mechanisms and treatment. Oxford (UK): Blackwell Futura; 2004. 352 pp. \$176.95 ISBN I405I-I888-I
Cyrenne P, Shanahan M. Private health care in the OECD: a Canadian perspective. Toronto: University of Toronto Press; 2004. I34 pp. \$17.95 ISBN 0-7727-86I5-I

Dambro MR. 2005 Griffith's 5-minute clinical consult. Baltimore: Lippincott, Williams \& Wilkins; 2005. I640 pp. \$90.95 ISBN 0-7817-5182-9

Fisher RG, Boyce TG. Moffet's pediatric infectious diseases: a problem-oriented approach, $4^{\text {th }}$ ed. Baltimore: Lippincott Williams \& Wilkins; 2004. 787 pp. \$53.44 ISBN 0-78I7-2943-2

Freimuth Marilyn. Hidden addictions. Maryland: Jason Aronson Publishers; 2005. 267 pp. \$45. ISBN 0-7657-0079-4

Golden RL. A history of William Osler's: The principles and practice of medicine. Montreal: Osler Library, McGill University; 2004. 265 pp. \$25 ISBN 0-77I7-0615-4

Goldman LS, Wise TN, Brody DS. Psychiatry for primary care physicians, 2 nd ed. Chicago: AMA Press; 2003. 49I pp. $\$ 78.50$ ISBN I-57947-4IO-I

Greenhalgh T, Robert G, Bate P, Macfarlane F, Kyriakidou O. Diffusion of innovations in health service organisations: a systematic literature review. Oxford (UK): Blackwell Publishing; 2005. 316 pp. \$150. ISBN 0-7279-I869-9

Haig AJ, Colwell M. Back pain. Philadelphia: American College of Physicians; 2005. 537 pp. \$45 ISBN I-9305I-359-3

Henderson KE, Baranski TJ, Bickel PE. Endocrinology subspecialty consult. Baltimore: Lippincott Williams \& Wilkins; 2004 234 pp. \$38.95 ISBN 0-7817-4378-8
Kavanagh KH, Knowlden V. Many voices: toward a caring culture in healthcare and healing. Madison (WI): University of Wisconsin Press; 2004. 312 pp. \$75.50 ISBN 0-299-I9760-3

King DJ. Seminars in clinical psychopharmacology, 2nd ed. London: Gaskell Publishing; 2004. 688 pp. \$6o ISBN I-90467Io8-X

LaRochelle WJ, Shimkets RA. The oncogenomics handbook. New Jersey: Humana Press; 2005. 750 pp. \$195 ISBN I-58829425-0

Liney, Gary P. MRI from A to Z: a definitive guide for medical professionals. New York: Cambridge University Press; 2005. 260 pp. \$34.99 ISBN 0-52I-60638-I

Loder EE, Martin VT. Headache: a guide for the primary care physician. Philadelphia: American College of Physicians; 2004. 287 pp. \$4I.95 ISBN I-930-5I3-38-0

Maricic M, Gluck S. Bone disease in rheumatology. Baltimore: Lippincott Williams \& Wilkins; 2005. 2II pp. \$I29.95 ISBN 0-78I7-530I-5

McLean R. Recovered, not cured: a journey through schizophrenia. Crows Nest (Australia): Allen \& Unwin Publishing; 2005. I92 pp. \$20.95 ISBN I-86508-974-5

Pampel FC, Pauley S. Progress against heart disease. Westport (CT): Greenwood Publishing Group; 2004. 233 pp. \$50.27 ISBN 0-275-98I5I-7

Richard C, Lussier M-T. La communication professionnelle en santé. Ville SaintLaurent, Que.: ERPI; 2005. \$89.95 ISBN 276I3-I5I8-9 